\title{
Studi Sintesis Analog Piokelin III: Sintesis Asam 3-Asetil-2-(2-(2-Hidroksifenil)- 4,5-Dihidrotiazol-4-II)Tiazolidine-4-Karboksilat
}

\author{
Adel Zamri \\ Jurusan Kimia FMIPA, Universitas Riau, Pekanbaru 28293 \\ email: adelzamri@yahoo.com
}

Diterima 02-06-2007

Disetujui 05-10-2007

\begin{abstract}
The total syntheses of 3-acetyl-2-(2-(2-hydroxyphenyl)-4,5-dihydrothiazole-4-yl) thiazolidine-4-carboxylic acid, a new pyochelin analog is described. The molecule intermediate 4'-(2-hydroxy-phenyl)-2,3,4,5,2',5,-hexahydro[2,2']bithiazolil-4-carboxylic acid was obtained in 4 steps reaction from 2-hydroxybenzonitrile in good yields. The $\mathrm{N}$ acetylation of molecule intermediate was carried out by acetic anhydride to produce pyochelin analog in moderate yields.
\end{abstract}

Keywords: analog, pyochelin, siderophore.

\section{PENDAHULUAN}

Piokelin 1 merupakan salah satu siderofor yang diproduksi oleh Pseudomonas aeruginosa dan Bulkholderia cepacia. Piokelin alami terdiri dari campuran dua stereoisomer $\mathbf{1 a}$ dan $\mathbf{1 b}$ yang merupakan hasil epimerisasi dari atom C-2" (Schlegel et al, 2004; Schlegel et al, 2006). Konfigurasi absolut dari piokelin alami 1a adalah (4'R), (2"R), (4"R) sedangkan diastereomernya 1b adalah (4'R), (2"S), (4"R). Epimerisasi ini disebabkan oleh sifat alami cincin tiazoilidin yaitu berupa basa "Schiff" yang mempermudah pembukaan ikatan C-S atau ikatan CN dari C-2" (Ponticelli et al, 1982; Ino \& Murabayashi 2001). Adanya gugus metill pada atom nitrogen yang bersifat pendorong elektron menyebabkan elektron bebas nitrogen akan lebih reaktif sehingga kemungkinan pembukaan cincin tiazolidin menjadi lebih besar (Ankenbauer et al, 1988; Zamri \& Abdallah 2000).

Untuk mengurangi keaktifan elektron bebas nitrogen tersebut maka pada tulisan ini dilaporkan sintesis analog piokelin $\mathbf{3}$ dimana gugus metilnya diganti dengan gugus asetil yang bersifat penarik elektron 4. Dengan demikian diharapkan elektron bebas nitrogen tersebut menjadi kurang aktif sehingga pembukaan cincin dapat dihindari. Sintesis analog piokelin 2 dilakukan sesuai dengan skema retrosintesis berikut (lihat Skema 1):<smiles>CN1[C@H]2SC[C@]1(C(=O)O)[C@@H]1CS[C@@H]2C1</smiles><smiles></smiles>

$1 b$<smiles>CC(=O)N1CSC[C@@H]1C(=O)O</smiles>

\section{BAHAN DAN METODE}

Bahan yang digunakan terdiri dari 2hidroksibenzonitril (Fluka), R dan S-sistein (Aldrich), $\mathrm{N}, \mathrm{O}$-dimetilhidroksilamin $\mathrm{HCl}$ (Aldrich), EDCl (Aldrich), LAH (Aldrich), dan DIEA (Aldrich). Pelarut yang digunakan terdiri dari diklorometana, etanol, etil asetat, dan THF. Peralatan yang digunakan adalah labu bulat leher tiga, kondensor, pengaduk magnet, rotary evaporator, pompa vakum, lampu UV, Buchi SMP-20, spectrometer NMR (Bruker, $500 \mathrm{MHz}$ ), dan Spektrometer massa (Fisons, Trio 2000). 


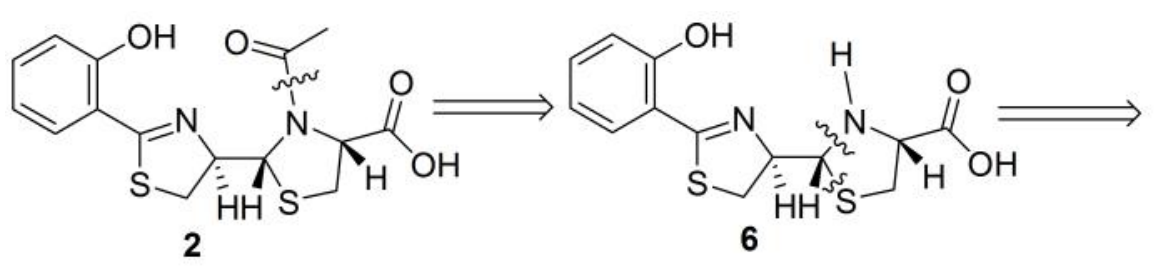<smiles>C=CC1CSC(c2ccccc2O)=N1</smiles><smiles>N#Cc1ccccc1O</smiles><smiles>C=C=C</smiles><smiles>O=C(O)[C@H]1CSC(c2ccccc2O)=N1</smiles><smiles>CN(C)C(=O)[C@H]1CSC(c2ccccc2O)=N1</smiles>

Skema 1. Analisis retrosintesis

\section{Metode sintesis asam 2-hiroksifeniltiazolin} karboksilat 3 (modifikasi metoda Zamri \& Abdallah 2000). 2-Hiroksibenzonitril (0,6 g, $5 \mathrm{mmol})$, (R) sistein $(1,21 \mathrm{~g}, 10 \mathrm{mmol})$ dilarutkam ke dalam campuran buffer fosfat $\mathrm{pH}$ 6,4 dan methanol 1:1 (20 ml). Campuran diaduk selama 36 jam pada temperatur 500C, saring dan pekatkan dengan rotari evaporator. Air $5 \mathrm{ml}$ ditambahkan, dan campuran diekstraksi dengan diklorometan $(3 \times 5 \mathrm{ml}$ ). Lapisan organik dicuci dengan air, larutan jenuh $\mathrm{NaCl}$, dan dikeringkan. Setelah penguapan pelarut dengan evaporator diperoleh padatan putih kekuningan, rekristalisasi dilakukan dengan etanol sehingga diperoleh padatan putih sebanyak 782 mg. Rendemen : 70,1\%. 1H-NMR (500 MHz, CDCl3): 3,51-3,76 $(2 \mathrm{H}, m), 5,42(1 \mathrm{H}, t, J=8,3 \mathrm{~Hz}), 6,89(1 \mathrm{H}$, t), 7,03 (1H, d), 7,34-7,65 (1H, m), 7,41 (1H, m). MS $(E I): m / z=223(55) ; 178(100) ; 119(17,2) ; 59(38,04)$.

Metode sintesis 2-(2-hidroksi-fenil)-4,5dihidrotiazol-4-karboksilat metoksi-metil-amida 4. Diklorometan $10 \mathrm{ml}$ (00C) ditambahkan larutan tiazolin 3 (2,20 g, $10 \mathrm{mmol})$, kemudian ditambahkan EDCI (11 mmol), dilanjutkan dengan penambahan larutan yang mengandung N,O-dimetilhidroksilamin $\mathrm{HCl}(1,07 \mathrm{~g}, 11$ mmol) dan DIEA (200 mg, 12 mmol) dalam diklorometan. Campuran reaksi diaduk selama 3 jam dan temperatur reaksi dibiarkan naik sampai temperatur kamar. Setelah penguapan pelarut, residu dimurnikan dengan kromatografi kolom (heksan/etilasetat) dan diperoleh padatan kuning sebanyak 2,23 g. Rendemen: 84\%. 1H-NMR (500 MHz, CDCl3): 3,28 (s, 3-H), 3,48 $(1 \mathrm{H}, J=9,2 \mathrm{~Hz}, d d), 3,77(1 \mathrm{H}, J=8,8 \mathrm{~Hz}, t), 3,81(1 \mathrm{H}$, $s), 5,70(1 \mathrm{H}, t, J=8,8 \mathrm{~Hz}), 6,88(1 \mathrm{H}, t), 6,98(1 \mathrm{H}, d)$, 7,34(1H, dd $), 7,42(1 \mathrm{H}, \mathrm{m}) . \mathrm{MS}(\mathrm{Cl}, \mathrm{NH} 3+):(\mathrm{M}+\mathrm{H})+=$ 267,2 (28); 237,2 (5); 236,2 (12); 178 (100).
Metode sintesis asam 2'-(2-hidroksifenil)2",3",4",5",4',5'-heksahidro-[2,4'] bitiazolil-4"karboksilat 6. Hidroksamat 4 (930 mg, 3,5 mmol) dilarutkan dalam THF (5 ml) dan larutan didinginkan 00C, LAH (137 mg, 3,65 mmol) ditambahkan sedikit demi sedikit lalu reaksi dibiarkan selama 20 menit. Kemudian berturut-turut ditambahkan metanol (1 ml), amonium klorida jenuh ( $1 \mathrm{ml}$ ) dan $\mathrm{HCl} 5 \%$. Campuran reaksi diekstraksi dengan etil asetat $(3 \times 5 \mathrm{ml})$, keringkan dan uapkan pelarutnya sehingga diperoleh aldehid 5. Tanpa pemurnian aldehid $\mathbf{5}$ dilarutkan dalam campuran etanol $(5 \mathrm{ml})$ dan air $(1 \mathrm{ml})$, potasium asetat (3 eq) dan ( $\mathrm{R}$ )-sistein $\mathrm{HCl}$ (4 mmol) dan reaksi diaduk selama 24 jam. Air ( $10 \mathrm{ml})$ ditambahkan, atur $\mathrm{pH}$ sampai 5,0 dan ekstraksi dengan etil asetat $(3 \times 5 \mathrm{ml})$, keringkan dan uapkan pelarut hingga diperoleh suatu busa berwarna kuning (640 mg). Rendemen: 59\%. 1H-NMR (500 MHz, CDCl3): 3,34-3,40 (2H, m), 3,49-3,74 (2H, m), 4,05 (1H, t, $J=7,1 \mathrm{~Hz}), 4,73(1 \mathrm{H}, \mathrm{d}, J=7,8 \mathrm{~Hz})$, 5,08 (1H, q, J = 8,3 Hz ), 6,89 (1H, m), 7,01 (1H, m), 7,38 (1H, m), 7,41 (1H, m). MS (FAB-); m/z (\%): 309,0 $[\mathrm{M}-\mathrm{H}]+(100)$. HR-FABMS (m/z): 311,0529 [M+H+] (dihitung 311,0524 untuk C13H15N2O3S2).

Metode sintesis asam 3-asetil-2-(2-2hidroksifenil)-4,5-dihidrotiazol-4-il)tiazolidin-4karboksilat 2. Ke dalam campuran asam 2'-(2hidroksifenil)-2",3",4",5",4',5'-heksahidro-[2,4']bitiazolil4"-karboksilat 6 (66 mg, 0,21 mmol), Na2CO3 (18 mg, $0,17 \mathrm{mmol}$ ) dalam campuran dioksan dan air 3:1 (4 ml) pada 00C, ditambahkan asam asetat anhidrid (26 mg, $0,25 \mathrm{mmol}$ ). Setelah pengadukan selama satu malam pada temperatur kamar, air (50 ml) ditambahkan dan diasamkan sampai $\mathrm{pH} 5,0$, ekstrak dengan EtOAc (3 x $10 \mathrm{ml}$ ). Lapisan organik dicuci dengan $\mathrm{NaCl}$ jenuh 
dan dikeringkan dengan natrium sulfat anhidrat, saring dan pekatkan dengan evaporator sehingga didapatkan busa berwarna kuning sebanyak $38,4 \mathrm{mg}$. Rendemen: 52\%. 1H-NMR (500 MHz, CDCl3: 2,15 (3H, s), 3,20$3,40(2 \mathrm{H}, \mathrm{m}), 3,45(2 \mathrm{H}, \mathrm{m}), 4,70(1 \mathrm{H}, \mathrm{m}), 4,90(1 \mathrm{H}, \mathrm{m})$, $5,30(1 \mathrm{H}, \mathrm{m}), 6,86(1 \mathrm{H}, \mathrm{t}, J=7,69 \mathrm{~Hz}), 6,98(1 \mathrm{H}, \mathrm{d}, J$ $=7,16 \mathrm{~Hz}), 7,34(1 \mathrm{H}, \mathrm{t}, J=6,8 \mathrm{~Hz}), 7,40(1 \mathrm{H}, \mathrm{d}, J=$ 7,46 Hz). MS (FAB-); m/z (\%): 351,0 [M-H]+(100) HRFABMS (m/z): 353,4285 [M+H+] (dihitung 353,4281 untuk $\mathrm{C} 15 \mathrm{H} 16 \mathrm{~N} 2 \mathrm{O} 4 \mathrm{~S} 2)$.

\section{HASIL DAN PEMBAHASAN}

Sintesis 2-hidroksitiazolin karboksilat 3 dilakukan sesuai dengan metoda Zamri \& Abdallah (2000), yaitu melalui kondensasi 2-hidroksibenzonitril dengan Rsistein dalam suatu larutan penyangga fosfat. Larutan penyangga fosfat berfungsi sebagai penstabil kation yang terbentuk dan mendorong siklisasi melalui serangan oleh atom nitrogen pada karbon yang teraktivasi (Huang et al, 1998). Kondensasi ini sering menimbulkan epimerisasi pada C-4 terutama bila dilakukan pada kondisi basa sehingga menghasilkan produk campuran $\mathrm{R}$ dan $\mathrm{S}$. Pada kondisi sedikit asam epimerisasi juga terjadi tetapi persentasenya relatif kecil yaitu sekitar 27,6\% (Zamri \& Abdallah 2000). Pemurnian enasiomer dilakukan rekristalisasi dalam etanol sehingga dihasilkan 2-hidroksitiazolin karboksilat yang relatif lebih murni dengan \% R/S = 97,2/2,8 (Gambar 1)

Tiazolin karboksilat 3 selanjutnya diubah ke turunan hidroksamat 4 melalui penambahan N,Odimetilhidroksilamin dan suatu agen pengaktif. Pada publikasi sebelumnya digunakan agen pengaktif DECP (dietilsianofosfonat), namun ditemukan epimerisasi pada C-4 dengan kemurnian optik senyawa $372 \%$ (Zamri \& Abdallah, 2000). Untuk menghindari masalah tersebut, pada tulisan ini dicoba menggunakan agen pengaktif $\mathrm{EDCl}$ (etilendiamin karbodiimid). Di samping harganya relatif lebih murah dibanding DECP ternyata hasilnya juga cukup baik. Dengan metoda ini epimerisasi dapat dikurangi menjadi $4-8 \%$, dan setelah proses rekritalisasi senyawa 4 diperoleh dengan kemurnian optik $97,7 \%$.

Sintesis senyawa 5 dilakukan dengan menggunakan metoda Zamri \& Abdallah (2000) yaitu reduksi senyawa 4 dengan litium aluminium hidrida (LAH) dan pembentukan cincin tiazolidin dengan

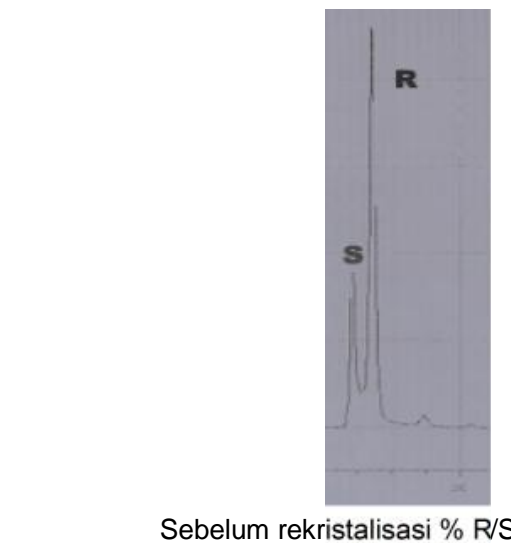

Sebelum rekristalisasi \% R/S $=72,4 / 27,6$

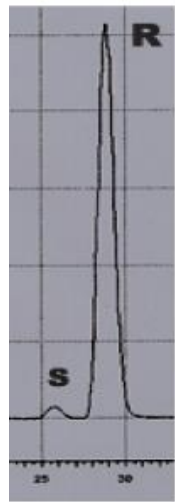

Setelah rekristalisasi \% $\mathrm{R} / \mathrm{S}=97,2 / 2,8$

Gambar 1. Kromatogram 2-hidroksitiazolin karboksilat (HPLC kolom Chiralcel OD, eluen Heksan/isopropanol 95/5, Kecepatan alir 0,5 ml/menit, Tekanan $19 \mathrm{PSI}$ )

penambahan R-sistein. Pada publikasi terdahulu (Zamri \& Abdallah 2000) sebagai pelarut digunakan eter, namun ditemukan kesulitan dalam "work up". Pada laporan ini digunakan THF dan hasilnya cukup baik terutama lebih mudah dalam pekerjaan "work up"(Skema 2). Aldehid 5 yang diperoleh langsung dikondensasikan dengan Rsistein dalam susana sedikit basa sehingga diperoleh senyawa 6 dengan rendemen moderat 59\%. Cincin tiazolidin yang terbentuk sangat mudah mengalami reaksi pembukaan cincin terutama dalam larutan melalui pemutusan ikatan C-S (Canle et al, 1996), dan penutupan kembali cincin melalui serangan atom $\mathrm{S}$ sehingga konfigurasi C-2" mengalami epimerisasi. Salah satu upaya untuk mengurangi reaktivitas elektron bebas dari atom $\mathrm{N}$ cincin tiazolidin adalah dengan mengikatkan gugus asetil pada atom $\mathrm{N}$ tersebut (Szilagyi \& Gyorgydeak 1979; Braibante et al, 1999).

Untuk maksud tersebut di atas, senyawa 6 diubah ke senyawa 2 melalui reaksi $\mathrm{N}$-asetilasi dengan menggunakan asam asetat anhidrid dalam air (Szilagyi \& Georydeak 1979) dan diperoleh rendemen yang moderat $52 \%$. Suatu hal yang sangat menarik adalah tidak ditemukannya O-asetilasi pada gugus fenol, hal 
<smiles>N#Cc1ccccc1O</smiles>

3<smiles>CON(C)C(=O)[C@H]1CSC(c2ccccc2O)=N1</smiles><smiles>[Z]C1([Y9])CSC(c2ccccc2O)=N1</smiles><smiles>C[C@H]1SC[C@H](C(=O)O)[C@@H]1C1CSC(c2ccccc2O)=N1</smiles>

6

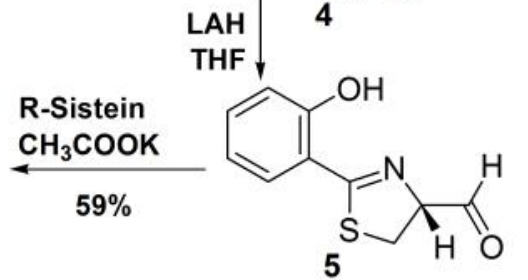

Skema 2. Sintesis analog pioklein 2 pyochelin, a siderophore of Pseudomonas aeruginosa. $\mathrm{J}$. Bacteriol 170: 5344-5351.

tersebut mungkin disebabkan atom $\mathrm{H}$ dari fenol tidak bebas karena terperangkap antara atom $\mathrm{O}$ dan atom $\mathrm{N}$ dari gugus tiazolin. Pengujian tingkat kestabilan analog piokelin 2 dilakukan dengan cara melarutkannya ke dalam kloroform dan didiamkan pada temperatur kamar selama 3 hari, hasil spektrum H NMR menunjukkan tidak adanya perubahan struktur molekul senyawa 2 tersebut.

\section{KESIMPULAN}

Asam 3-asetil-2-(2-2-hidroksifenil)-4,5-dihidrotiazol4-il)tiazolidin-4-karboksilat 2 telah berhasil disintesis dari molekul awal 2-hidroksibenzonitril dalam 5 tahap reaksi dengan rendemen total $18 \%$. Senyawa yang diperoleh menunjukkan tingkat kestabilan struktur lebih baik dibandingkan dengan piokelin alami.

\section{UCAPAN TERIMA KASIH}

Ucapan terima kasih disampaikan pada DIKTI melalui proyek Hibah Bersaing XII atas bantuan dana risetnya dan Mr. Roland Gross dari Universitas Louis Pasteur untuk bantuan pengerjaan spektrum NMR dan MS.

\section{DAFTAR PUSTAKA}

Ankenbauer, R.G., Toyokuni, T., Staley, A., Rinehart, Jr., K.L., \& Cox, C.D. 1988. Synthesis and biological activity of
Braibante, M.E.F., Braibante, H.S., \& Costenaro, E.R. 1999. The use of Curtius rearrangement in the synthesis of 4aminothiazolines. Synthesis 6: 943-946.

Canle, M., Lawley, A., McManus, E.C., \& More O'Ferall, R.A. 1996. Rate equilibrium constans foe oxazolidine and thiazolidine ring-opening reactions. Pure \& Appl. Chem. 68: 813-818.

Huang, T,C., Huang, L,Z., \& Ho, C,T. 1998. Mechanistic Studies on Thiazolidine Formation in Aldehyde/Cysteamine Model Systems. J. Agric. Food Chem. 46: 224-227.

Ino, A. \& Murabayashi, A. 2001. Synthetic studies of thiazoline and thiazolidine-containing natural products. Part 3: total synthesis and absolute configuration of the siderophore yersiniabactin. Tetrahedron 57: 1897-1902.

Ponticelli, F., Marinello, E., \& Missale, M,C. 1982. Cis-trans isomerization of 2-(4-pyridyl)-substituted thiazolidine-4carboxylic acids; $\mathrm{pH}$ dependence by $1 \mathrm{H}$ and $13 \mathrm{C}$ NMR. Org. Magn. Res. 20: 138-140.

Schlegel, K., Taraz, K., \& Budzikiewicz, H. 2004. The stereoisomers of pyochelin, a siderophore of Pseudomonas aeruginosa. BioMetals 17: 409-414.

Schlegel, K., Lex, J., Taraz, K., \& Budzikiewicz, H. 2006. The X-Ray struktur of pyochelin Fe+3. Z. Naturforsch 61c: 263266.

Szilagyi, L. \& Gyorgydeak, Z. 1979. Comments on the putative stereoselectivity in cystein-aldehyde reactions. Selective $\mathrm{C}(2)$ inversion and $\mathrm{C}(4)$ epimerization in thiazoline-4carboxylic acids. J. Am. Chem. Soc. 101: 427-432.

Takuma, S., Hamada, Y., \& Shioiri, T. 1982. An extensive survey by the use of high performance liquid chromatography on racemization during the coupling of benzyloxycarbonyl-Lphenylalanyl-L-valine with L-proline- $t$-butyl ester. Chem. Pharm. Bull 30: 3147-3153.

Zamri, A. \& Abdallah, M.A. 2000. An improved stereocontrolled of pyochelin, Siderophore of Pseudomonas aeruginosa and Burkholderia cepacia. Tetrahedron 56: 249-256. 